\title{
Cinematic Conversion in Frank Wisbar's Dogs, Do You Want to Live Forever?
}

\section{Abstract}

During the 1950s, West German cinemas screened approximately 600 war films, nearly ten percent of the domestic production. Faulting these features for their avoidance of significant issues such as the causes of World War II, the Holocaust, or the Wehrmacht's misdeeds and atrocities, previous commentators have in the main focused on the failure of these films to engage the past in a thoroughgoing manner. As a response to this criticism, my essay will show how Frank Wisbar's Dogs, Do You Want to Live Forever? (1959), a feature film about the Battle of Stalingrad, provides a conversion narrative that corresponds to the needs of the Adenauer era. As this film looks back to its past, it simultaneously looks forward and promotes the values of a new and emerging democracy.

Keywords: Battle of Stalingrad, war films, Adenauer era, 1950s West German Cinema, World War II

West German war films of the 1950s attempted to negotiate a problematic past through a variety of narratives. Alfred Weidenmann's The Star of Africa (1957), for instance, revisited the exploits of flying ace Jochen Marseille in the skies above North Africa, while Harald Reinl's U47 Lieutenant Prien (1958) turned to the sea in its treatment of the famous submarine commander. Other military films like J.A. Hübler-Kahla's Mikosch Arrives (1952) or Franz Peter Wirth's Heroes (1958) avoided the time and setting of World War II altogether, opting for comic representations. But few films dealt more directly and explicitly with Germany's failure than Frank Wisbar's Dogs, Do You Want to Live Forever? (1959). Wisbar's war movie focused on what many considered to be the turning 
point of the war, the Battle of Stalingrad. Following the experiences of the fictional Lieutenant Wisse in the middle of a real historical event, Wisbar's film explores the questions of German responsibility for the tragic defeat.

In this essay, I will argue that Dogs, Do You Want to Live Forever? is built upon a conversion narrative that accommodates German citizens and history to the Federal Republic of the 1950s. The film's protagonist, Lieutenant Gerd Wisse, begins as an idealistic Hitler supporter, but ends as a bitter prisoner-of-war (POW), aware that the Führer and his senior leadership have abandoned him. The development of the main character was certainly nothing new in war movies: "[c]onversion is a central narrative structure and strategy for the wartime film," argues Dana Polan ("Auteurism" 77). But the transformation that occurs in Dogs offers a variation on the more typical Hollywood version that involved molding a selfish civilian into an enthusiastic warrior. In the span of just over ninety minutes of cinematic time, Wisse goes from a committed Nazi to a future member of the Federal Republic. Conversion also occurs in historical terms as Wisbar takes the German defeat at Stalingrad and turns it into a useful narrative for 1950s' West Germany. The Wehrmacht still loses the battle, but the film allows Germans to more easily navigate their past.

\section{Bringing a Tragedy to the Big Screen}

Converting a tragic military defeat into big screen entertainment for the German audience was no small feat. The Germans lost approximately 60,000 soldiers with another 110,000 taken prisoner, of whom only around 5,000 would return to Germany by 1955 (Moeller, "In a Thousand Years" 161). Some believed West Germans were not yet ready for a film depicting the infamous battle. The Chief of Staff of the Bundeswehr, General Adolf Heusinger, wondered how many wounds such a film would reopen ("Frei”). Any depiction of Stalingrad would also have to contend with the emotional trauma associated with such a devastating defeat at a time when most Germans were trying to rebuild their lives in a newly formed nation. The Battle of Stalingrad not only served as a painful reminder of the lost loved ones but also marked the beginning of the Third Reich's downfall. The only film to deal exclusively with the Battle of Stalingrad in the 1950s, Dogs, Do You Want to Live Forever?, played to packed movies houses, earning national recognition as well. The feature received a West German film prize of 100,000 DM as the second-best film of 1959 from the Interior 
Ministry (Moeller, War Stories 149). At the box office, Dogs finished sixth in the year that saw more than 670 million tickets sold in the Federal Republic (Sigl et al.133). Furthermore, Wisbar's film contributed to the discourse on Stalingrad in the 1950s, arousing both consternation and praise from politicians, the media, and the public. For example, Erich Kuby, journalist and author, claimed that Dogs, Do You Want to Live Forever? signaled the preoccupation of West Germans in the postwar era with winning the war that had been lost (210).

Wisbar's film begins with documentary footage of a military formation passing before Hitler in Berlin. After archival footage of frozen corpses, the action shifts to a military briefing where Hitler insists the Sixth Army, stopped just short of Stalingrad, take the city. Wisbar then introduces us to the film's protagonist, Wisse, a young, blonde First Lieutenant of the Wehrmacht, equipped with shiny boots and German shepherd at his side. The narrator and titles announce the date and location as Kharkov 1942. On his way to the front, Wisse meets the bilingual Russian, Katja, and arranges for her to get a job with his friend Lieutenant Fuhrmann so that she will not be deported. Before reaching his new unit, Wisse runs into the seasoned commander, Lieutenant Colonel Kesselbach, and Chaplain Busch, who inform him of the real situation in Stalingrad. Upon arrival at his new posting as the liaison officer to Romanian General Codreanu, he immediately learns of the Soviet buildup of forces and the lack of heavy weapon support on the German side. His new boss, Major Linkmann, a loyal Hitler supporter, downplays the threat of an enemy attack, warning Wisse to be leery of the Romanians and denigrating them as bad soldiers.

When the Russians quickly attack, Wisse responds heroically, taking out an enemy tank singlehandedly, while the gun-shy Linkmann flees. After the Soviets encircle the Sixth Army, Hitler refuses to give the order to attempt a breakout. General von Seydlitz takes matters into his own hands, preparing his units for combat, but cannot persuade Paulus to issue marching orders. Another opportunity to escape arises after General Hoth's Army comes to assist, but the Field Marshall refuses again, citing a lack of fuel. Having lost faith in their leaders, the soldiers celebrate a subdued Christmas while continuing to run out of food and ammunition.

Wisse receives a new assignment as a battery commander where he reunites with his friend, Fuhrmann, and his nemesis, Linkmann. In an attempt to commandeer any remaining supplies, Wisse leads a group of soldiers to a military airport, from which the last airplane to Germany 
departs. Linkmann sends Wisse to a field hospital in search of more soldiers for a last-ditch fight against the Russians. Amidst the cries of misery from hundreds of wounded, he finds his friend Fuhrmann, who dies in his arms. Returning to action in the ruined city, Wisse, disguised as a Russian soldier, comes across Katja in a soup line. Returning his earlier favor, she helps him to escape, but declares their friendship over. Paulus finally makes the decision to surrender. Wisse also surrenders and joins Krämer, Kesselbach, and Busch in their march to the prisoner camps.

\section{Conversion West German-Style}

Like many war movies, Dogs, Do You Want to Live Forever? is a conversion narrative. Typically, as Dana Polan elaborates, such stories depict the process whereby an indifferent soldier becomes a dedicated warrior:

If, as the war discourse will often argue, an individual gets out of place because he/she has internalized incorrect beliefs and values, then a potent narrative recovery from the violence of this bad internalization will be one in which an individual converts to a new and proper set of values and beliefs (Power 75).

In the American war movie, Allan Dwan's Sands of Iwo Jima (1949), for example, a young Private Conway endures demanding training from his squad leader, Sergeant Stryker, played by John Wayne. While other squads enjoy liberty, Stryker takes his group on grueling road marches or puts them through bayonet drills. The difficult preparation finally pays off when the squad enters combat. After Stryker saves Conway's life, the once cynical figure realizes the debt he owes the tough Sergeant and fights heroically in the ensuing combat sequences. Before the Marines raise the flag at Iwo Jima, however, the Japanese shoot Stryker dead. Conway symbolically picks up Stryker's flag and vows to carry on the Marine tradition instilled in him by his squad leader.

Unlike Private Conway, who experiences "total" conversion of "mind" and "body" (Polan, Power 75), only Wisse's mind is at stake in Wisbar's movie. Arriving at the front with the top credentials of a National Socialist upbringing, Wisse displays an enthusiasm and eagerness to carry out his duties, a willingness to serve, and a consideration for others. He anxiously awaits his marching orders to the front while showing sympathy for the German-speaking Russian woman, Katja, 
sharing an early tender moment with her, which highlights his ability to connect with his fellow characters.

The first source of tension for Wisse, the initial crack in the armor of his ideological faith, occurs in a Stalingrad-bound railcar when he refuses to believe that all is not well on the Eastern Front. Later, after he witnesses some Russian children praying, he takes pride in having been taught as a National Socialist to rely only on himself. After learning that the Russians have encircled the Sixth Army, he reprimands Krämer for suggesting that Hitler has lost his mind. As the situation in Stalingrad degenerates, Wisse gradually learns to trust his subordinates and begins to question the motives of his superiors. The severe cold and lack of food also begin to take their toll on the protagonist and his fellow troops. In Wisbar's film, the "body" thus affects the "mind," instead of the other way around. Ultimately, Wisse comes to recognize Hitler's incompetence and the lies underlying National Socialism. Rather than an affirmation of fate, Wisse's loss of faith in his leadership indicates the opposite of more typical conversion experiences. His transformation culminates in his refusal to obey Linkmann's orders as he calls his superior a "coward."

Linkmann plays an important role in Wisse's transformation as well. The Major represents a foil to Wisse as the genuine Nazi. Unlike the caring and capable Wisse, Linkmann personifies incompetence, cowardice, and inhumanity. The first view of Major Linkmann shows him sitting at a desk playing solitaire while the Russian troops approach. The image will be repeated, demonstrating the Major's incompetence and his willful blindness to reality. Having already warned the new liaison officer not to trust the Romanians, Linkmann later alludes to Hitler's secret plan to have them used as cannon fodder. When Wisse displays courage by destroying a Russian tank, Linkmann proves himself a coward as he attempts to commandeer a vehicle and flee the scene. The young lieutenant keeps his subordinates informed of the dire situation while Linkmann reprimands him for telling the truth. Toward the end of the film, Wisse places his coat on his dying friend Fuhrmann, after which he returns to inform Linkmann, who displays no concern whatsoever for the soldier's death. In contrast to Wisse, who repeatedly appears in the presence of other soldiers on the screen, Linkmann remains alone and isolated.

The portrayal of Linkmann closely matches that of Wisbar's on-screen recreation of Adolf Hitler. The cowardly Major prefers to retreat to his office just as Hitler did to his bunker (Moeller, "In a 
Thousand Years" 166). Wisbar often positions Linkmann and Hitler on the edges of the frame, suggesting that they are out of touch with reality. Both underestimate the Russian threat and have little regard for the loss of German life. After hearing the news that the Sixth Army has been vanquished, Hitler unsympathetically orders the building of a new one. This sequence appeared in both the short and long versions of the film's trailer, thus displaying the production's emphasis on the Nazi leader's lack of humanity. The film fails to address Hitler's policy of extermination, but the potential of his brutality is implicit in the Nazi leader's treatment of the Romanians and his own military. Like other West German war films of the 1950s, Wisbar assigns primary responsibility for the catastrophe to Hitler and his fanatical followers, in this case represented by Linkmann.

Instead of forcing Germans to closely reexamine their own actions during World War II, Dogs, Do You Want to Live Forever? allows the audience to embrace the notion that they were merely misled. In order to distance the ordinary German from National Socialism, the film redefines Nazis as incompetent and crazed cowards. Wisse, on the other hand, possesses all the traits necessary to assist a rearmed Germany. Thus, his transformation can stand in for the potential transformation of German society as a whole. Moeller notes "[Wisse]... provided evidence that good [looks], valor, and honor could be packaged differently; he was the "citizen in uniform"' ("In a Thousand Years" 173). Wisse displays all the characteristics of a fine leader: courage (he single-handedly takes out a tank), candor (he tells his men the truth of their dire situation), competence (he is a capable combat leader), and commitment to his soldiers (he stays with them to the end). Similarly, he bears no ill will toward his Soviet enemies: he enjoys a friendship with the Russian woman, Katja, and returns a captured Red Army soldier back to his lines.

Religion also plays an important role in the transformation of Wisse as he gradually learns its value in comparison to the self-reliance preached by National Socialism. In one scene, Wisse takes the prayers of Russian children as confirmation that Bolshevism cannot replace Christianity. Later in the film, Wisse notices that even the bleakest conditions in Stalingrad cannot dampen spirits at the Christmas service celebrated by Pastor Busch. Finally, Wisse stands as an example to the new Germany in breaking down class barriers. Although he was criticized for the abundance of officer roles in the film (Kotulla 117), Wisbar emphasizes the importance of Wisse's contact with the enlisted ranks. Constantly surrounded by his soldiers, Wisse begins to see the war as they do. The 
lieutenant experiences first-hand the failures of Hitler's military leadership. The characters who fail to connect with their subordinates, Hitler, Linkmann, and Paulus, ultimately make the wrong decisions which lead to the destruction of the Sixth Army. The filmmaker frames Hitler, Linkmann, and Paulus in the confines of sterile briefing rooms devoid of contact with the outside world.

In addition to the fictional Wisse, Wisbar transforms the historical figure of General Walther von Seydlitz. Wisbar's positive portrayal of the general, who served as an advisor to the film (Richnow), contradicted the opinion of most Germans who still considered him a traitor (Moeller, War Stories 114-15). Unsurprisingly, Wisbar portrays Seydlitz as a true patriot who takes matters in his own hands, ignoring Hitler's orders and trying to save the lives of German soldiers. His portrayal contrasts with that of General Paulus, who strictly follows Hitler's dictates. In attempting to convince Paulus to break out of the encirclement, Seydlitz claims that his loyalty belongs to the nation rather than to an individual. Wisbar further associates Seydlitz with the Prussian militaristic past when he cites the decision of General Yorck von Wartenburg to disobey Frederick the Great. Seidlitz's loyalty to the nation thus represents a return to a military tradition upon which a future Army could build.

Thus, Wisse embodies the citizen-soldier of the new Federal Republic. Like Seydlitz, he trusts his instincts and challenges authority. In the lieutenant's first appearance, he immediately challenges the "order is an order" notion, lands a job for Katja, and then departs for the front.

\section{Recreating History through Recycled Images and Sound}

In addition to the film's conversion narrative, Wisbar also reconstructs the Battle of Stalingrad into a viable narrative for the Adenauer era. Like other war films of the 1950s, the narrative highlights the dangers of blind obedience and the need to question authority. Most of the blame for the battle's outcome falls on the poor decisions of Hitler and Paulus, with Wisbar using extensive newsreel footage to back up his claims. Like Fritz Wöss, author of the book upon which the film is based, Wisbar's narrative emphasizes missed opportunities and squandered chances that could have prevented or at least minimized the tragedy. Furthermore, Dogs, Do You Want to Live Forever? both reinforces the heroic sacrifice of the German soldier initiated in the National Socialist era and expands the status of the Wehrmacht as "victim." Several scenes depict the suffering of 
the Army at the hands of the enemy, the cold weather, and the Wehrmacht's senior leadership. In contrast to the German suffering, the suffering inflicted by the German Army on the Russian soldiers and local population goes largely ignored.

Wisbar omits all credits at the start of his film, beginning instead with archival footage, which immediately lends a documentary feel to his project. Cinematographer Helmut Ashley employed a combination of studio shots, outdoor battle sequences, and both German and Russian documentary footage. One of Ashley's major contributions was the seamlessness with which he blended these different materials (Roos). Even today, it is difficult at times to distinguish between live action and archival footage. In addition to giving the film a more authentic feel (Paul 45), the use of newsreel images allowed for the representation of combat scenes that would have been extremely difficult to replicate.

The newsreels also underscore the real-life consequences of Hitler's and Paulus's decisions. Wisbar repeatedly sets up a cause and effect paradigm when using the archival material. In the earliest moments of the film, he uses the footage of a military parade in Berlin highlighted by goose-stepping Nazis. These images then yield to a newsreel of dead soldiers in the winter wastelands of the Russian steppe. With these juxtapositions, the film suggests that the militarism of the Nazis leads directly to the death and destruction of German soldiers. Later in the film, the Nazi leadership's underestimation of the Russians will give way to ensuing newsreel footage of the Russian advance and eventual encirclement of the Sixth Army. In the movie's final moments, Hitler's lack of concern for his soldiers in Stalingrad yields to recycled images of German soldiers beginning their trek toward almost certain death in Russian POW camps.

Voice-over narration plays a critical role as an accompaniment to these newsreels; it establishes time and location for the viewer and adds to the documentary feel of Wisbar's project as well as providing an indirect commentary. Once again, the opening sequence sets the tone for the rest of the movie. The narrator explains that the archived shots of dead soldiers show the battlefields of Stalingrad, followed by a statement that victory is of no concern to a dead soldier. At the end of the film, Wisbar replaces the narrator with a musical soundtrack as strings set a tragic tone to accompany the pictures of German POWs trudging through the snow. 
Wisbar brings sound to the forefront in his replaying of Hermann Göring's speech, delivered three days prior to the Sixth Army's surrender. Göring correctly anticipated the attention the Battle of Stalingrad would receive, but he expected a final German victory, not a defeat. Wisbar uses the speech as the background to the scene in a makeshift field hospital where German soldiers lie wounded and dying. Instead of providing an enthusiastic response, the wounded soldiers yell for the speech to end; the chaplain will eventually break the radio.

In the film's rebroadcast of the radio address, Göring speaks of the battle in the past tense, placing Stalingrad within the same "mythical firmament" as the battles of the Nibelungs and of Thermopylae (Moeller, "In a Thousand Years" 162). Göring compares the heroic struggle of the Sixth Army to that of the under-manned Spartan army against the Persians and to the epic fight to the death of the Nibelungs (Reichel 84). The Nazi government used Stalingrad to highlight the "heroism" and "sacrifice" of the German Sixth Army (Wette 43-60; Reichel 84-85; Moeller, "In a Thousand Years"161-90). Göring also referred to heroic sacrifice as the highest of soldierly values (Wette 52). The notion of the heroic struggle continued in the discourse surrounding Stalingrad in the 1950 s and into debates more than fifty years later.

Wisbar's 1959 cinematic creation of Stalingrad in 1943 portrays the death of the soldiers as noble but meaningless. He assigns responsibility for the images of dead and wounded soldiers to Nazi leaders like Göring. The field hospital scene also follows others that clearly blame Hitler and Paulus for the soldiers' predicament. Yet Wisbar does not completely condemn the sacrifice of the Wehrmacht. We see an image of Lieutenant Fuhrmann holding up his handless arms, but also hear of his struggle to continue the fight. Earlier we also witness Wisse single-handedly take out a tank with a grenade. With the exception of the Nazi supporter, Linkmann, all soldiers in the film fight bravely and heroically. The Wehrmacht thus maintains its image as a misled yet respectable institution. During the Adenauer era, West Germany looked to the newly-created Bundeswehr to secure its nascent democracy, and, if necessary, to defend it courageously from Soviet aggression.

\section{From Words to Celluloid: Storybook Images of Stalingrad}


The scene in the field hospital is one of the several captured by Helmuth Ellgaard in the sketchbook that accompanied the official press packet. Ellgaard's drawings include images inspired by Wisbar's research and earlier literary accounts. As Robert G. Moeller notes: "Wisbar did not create a completely new framework for understanding the 'sacrifice' of the Sixth Army; rather, Hunde clearly expressed meanings that had evolved since 1943, telling movie audiences what they already knew and were eager to hear again" ("In a Thousand Years" 164). German filmgoers may have been familiar with the notions of Stalingrad, but Wisbar's movie enabled them to see and experience the battle on the big screen. A mixture of live action, special effects, and newsreel footage brought combat in and around the demolished Russian city to life. One of Ellgaard's pictures recreates such a scene as a Wehrmacht soldier runs for cover among the ruins of the city, but the majority of the sketchbook, like the film, has less to do with fighting the Red Army than emphasizing the failures of Hitler and Paulus. Again, the senior leadership of the military is condemned, while the myth of the noble soldier remains intact.

Dogs, Do You Want to Live Forever? brings to celluloid life images previously restricted to verbal form in novels, historical accounts, memoirs, and letters. Beginning with Theodor Plievier's Stalingrad, numerous literary accounts filled the shelves of West German bookstores. Published in 1947, Plievier's work recounted the horrors of the battle and the deplorable conditions that the Wehrmacht faced. Later works, like Heinrich Gerlach's The Betrayed Army, would continue to portray the suffering borne by all ranks of soldiers (Wieder 362). The blame for the tragedy falls mainly on Hitler. This became especially transparent in the memoirs of several high-ranking generals, including those of Erich von Manstein, commander-in-chief of the Army group to which the Sixth Army was subordinate. Military leaders also claimed that Stalingrad was unnecessary and preventable. In addition to the vivid descriptions found in works like Plievier's, these accounts also focused on the missed opportunities that could have changed the outcome of the battle.

Wisbar based Dogs, Do You Want to Live Forever? on three literary works: Fritz Wöss's 1958 novel of the same title, Heinz Schröter's Stalingrad “... to the last Bullet” (1953), and Last Letters from Stalingrad (1950), published anonymously, but attributed to Schröter. These works show up early in the film in a medium shot of all three books lying next to each other on top of a map. The camera slowly moves to a close-up of the title of Wöss's book which provides the film's title. 
Wöss's novel was the most popular Stalingrad book of the 1950s (Kumpfmüller 226). It broke from other literary representations in its "radicalization" and "popularization" of Stalingrad's missed chances and its emphasis on the view from below (Baron 232; Kumpfmüller 226). Wöss bases his protagonist, Captain Wisse, on his personal experiences, and attempts to tell the "truth" about the battle (Reichel 93).

Unlike Wöss, Schröter's historical reportage, Stalingrad “...to the last Bullet," focuses on Stalingrad from "above" by reporting on meetings among leaders at the highest levels. The author served as war correspondent in a propaganda company that barely escaped Stalingrad before its collapse (Ueberschär 94). Following the surrender of the Sixth Army, Goebbels assigned Schröter to write a history of the battle, allowing him access to a variety of resources such as maps, correspondence, and transcripts of radio messages (Ueberschär 94). Goebbels rejected the account because of its critical nature, but Schröter retained the manuscript, and returned to it after the war (Wieder and von Einsiedel 301). Historians have approached Schröter's book with caution, pointing to many false datings of documents and unidentifiable sources (Wieder and von Einsiedel 301). Deutsche Film Hansa requested the right to use Schröter's title, but legal problems prevented this, forcing the producers to borrow the title of the film from Wöss' book (Soldatenzeitung). Schröter also assisted Wisbar in the writing of the screenplay.

Attributed to Schröter based on the similarity in style to Stalingrad "...to the last Bullet," Last Letters from Stalingrad, published anonymously in 1950, contains thirty-nine letters from soldiers addressed to the loved ones in Germany shortly before the capitulation of the Sixth Army (Wieder and von Einsiedel 301). Apparently, the high command of the Army had intercepted these letters in order to gauge the "true feelings" of the troops (Wieder and von Einsiedel 301). In a short survey published at the end of the compilation, 57 percent of the soldiers stated that they mistrusted or rejected the military leadership (Wieder and von Einsiedel 301). Recently, the authenticity of the letters has been determined to be "very much in doubt" and the collection classified as fiction (Beevor 485).

\section{German Suffering on the Big Screen}


Dogs, Do You Want to Live Forever? foregrounds images of German suffering. The culmination of the Wehrmacht's misery occurs in the previously mentioned field hospital scene. Wisbar sets up the scene with Linkmann telling Wisse that he is to look for cowards pretending to be hurt. However, Wisse finds only soldiers that have fought heroically and have the wounds to prove it. The filmmaker spared no expense in attempting to recreate the scene. According to Joachim Hansen, who played Wisse, the director gathered nearly two hundred wartime amputees from the area surrounding the studio. Having them take off their prosthetic devices, adding bandages and make up, he instructed them to act just as they had when they were wounded some ten years earlier ("Interview"). During a visit to the filming, Seydlitz noted how the scene appeared "as then just as then" (Miska). The camera repeatedly pans over the soldiers' amputated limbs including Wisse's piano-playing friend Fuhrmann, who has symbolically lost both his hands. Wisbar clearly assigns blame for the soldier's agony to the Nazi leadership represented by Göring's voice.

In addition to the cold weather and lack of food, the Battle of Stalingrad became associated with images of German POWs. As Moeller notes:

the defeat at Stalingrad in February 1943 marked the moment when German citizens fully realized that the war had gone sour; for them, this decisive Soviet victory was permanently associated with massive casualties and the removal en masse of thousands of German soldiers to POW camps (War Stories 10).

The status of these POWs held in the Soviet Union was a major concern during the Adenauer era. Nearly three million soldiers were held in Soviet captivity and from those nearly one million died (Moeller, War Stories 3). Additionally, many families had to wait for a long period of time for the return of their loved ones. The last POWs were not released until 1955, following a highly publicized visit to Moscow by Chancellor Adenauer (Moeller, War Stories 88; 96-105). Initially, these former Wehrmacht soldiers were the subject of great attention in German society as a representation of German victimhood. The relationship of West German society with these POWs, as well as with the German refugees from the East in the final years of the war, allowed Germans to focus on their own suffering instead of the suffering they inflicted on others. Later in the 1950s, the former POWs came to be known primarily as survivors and not as Hitler's former soldiers. They 
could, therefore, become valuable contributors to Germany's reconstruction (Biess 58). Traveling exhibitions about POWs showed how they "asserted themselves spiritually," displayed "humanity in the midst of inhumanity," and retained their beliefs in "freedom," "home," and "family" (Biess 67). Free of their connection to the past, they could thus be fully reintegrated into the Adenauer era as leaders of their families, emerging businesses, and newly formed democratic institutions.

The final scene of suffering involves the last plane out of Stalingrad. In this scene, hundreds of soldiers fight over the remaining few seats on the last flight to Germany. The famished Sergeant Kunowski from Wisse's unit tries to jump on board, searching for any last crumb of food, breaking his neck against the wing of the airplane in the process. As in the scene in the hospital, we see several shots of wounded soldiers. The scene emphasizes the abandonment of the Sixth Army by the Nazi leadership and specifically by Hermann Göring, the chief of the Air Force, who refused to allow any more flights in support of the troops encircled around Stalingrad. Following the scene, Göring's lack of concern carries over into the unsympathetic Major Linkmann, who ignores Kunowski's death.

By concentrating solely on the suffering of German soldiers, the narrative ignores the death and destruction caused by the Sixth Army. Compared to 60,000 Wehrmacht casualties, the Red Army lost nearly 155,000 as well as more than 330,000 seriously injured or wounded troops (Beevor 434-40; Hettling 524; Overmans; Krivosheev et al. 17; Glantz and House 141-42). Additionally, the participation of Wehrmacht elements in atrocities is neither depicted nor mentioned. Prior to arriving in Stalingrad, the Sixth Army left a trail of destruction, actively participating in the deaths of over 30,000 Jewish civilians at Babi-Yar and some 22,000 at Kharkov, the city depicted in the film's opening (Moeller, "In a Thousand Years" 186).

\section{Images of Homeland, Soviet Friendship, and Atomic Rearmament}

In his examination of the depictions of the Holocaust and World War II in German film and theater, Peter Reichel indicates that the longing for the homeland (Heimat in German) figured in cinematic memories of Stalingrad (86). The scene involving the last plane out of Stalingrad represents both 
the soldiers' will to survive and their overwhelming desire to return to their homeland. We also see a traffic signpost that lists various distances to Russian towns and notes that Berlin is almost 3,000 kilometers away. The arrow pointing toward Berlin demonstrates the important place it occupied for most Germans. The longing for the homeland can also be found in the Christmas scene. Wisse and his soldiers visit a makeshift holiday celebration complete with a Christmas tree and a chorus of "Silent Night." Holiday rituals frequently appear in war films of the 1950s and reflect a desire to preserve the influence of Christian culture.

Besides the images depicting the longing for the homeland, Dogs, Do You Want to Live Forever? includes scenes that cast Soviet-German relations in a positive light. Both sides appear as reluctant participants in a war that was not of their choosing. This attitude culminates in the ceasefire scene, where each side agrees to a pause for thirty minutes to collect their dead. During this time, both sides listen to Fuhrmann play Beethoven on a piano in the midst of the rubble. A shot of Wisse followed by a countershot of a dead soldier invites the audience to mourn both Russian and German deaths. Both sides fight bravely and honorably. Wisse even releases a Russian prisoner back to his lines instead of shooting him. On the Russian side, the worst behavior we see is a Russian soldier ripping the coat off Wisse after they take him prisoner.

Playing to West German audiences during the early stages of rearming, Dogs condemns the highest levels of military leadership without condemning war in general. It does, however, show the catastrophic effects of blind allegiance. Sparing no images of the horrifying aspects of combat, Wisbar's project offers its viewers a world in which soldierly virtues of loyalty, duty, selfless service, honor, and courage can exist under the guidance of proper leadership.

While considered neutral with respect to the debate concerning conventional rearmament, Dogs, Do You Want to Live Forever? reflects the anti-atomic weapon movement of the later 1950s. Nuclear weapons actually first appeared on German soil in 1953, as tactical weapons of the United States military. The public debate did not begin, however, until 1955, following a discussion of NATO's defense plan that stressed the importance of nuclear weapons over conventional forces. Two months later, in June 1955, German fears of nuclear war surfaced following a NATO-led exercise which simulated a nuclear attack on Germany. Initially, Chancellor Adenauer resisted calls for the deployment of nuclear weapons in defense of Germany, but later succumbed to United 
States pressure. He agreed to arm the Bundeswehr with tactical nuclear weapons in October 1956. In April 1957, a group of scientists declared their opposition to the deployment of nuclear weapons. A huge public debate ensued, with nearly 64 percent of the West German population voicing their opposition to arming the Bundeswehr with nuclear weapons. Despite this negative response, Adenauer's party won a landslide victory in the elections of 1957, and Adenauer presented his party's plan to outfit the military with tactical atomic weapons in March of 1958. Once again, a bitter fight ensued between the political parties. Many referred to a potential nuclear conflict as a second Stalingrad, coining the phrase "Nuclear War-Stalingrad" (Reichel 95).

One could easily draw analogies between the encirclement of Stalingrad and the prospective encirclement of West Germany as a potential site of nuclear war, targeted by both Soviet Russia and the United States. Parallels could also be drawn between the impact of the poor decisionmaking by Hitler regarding Stalingrad and a potentially even more lethal decision to launch an atomic attack. Some critics saw the film as a means to raise this important issue ("Nicht im Interesse"). Wisbar issues an implicit warning about a potential nuclear war at the end of the film when an officer speculates that perhaps Germany has learned from what has happened at Stalingrad, to which Private Krämer responds that maybe it has not.

In conclusion, Dogs, Do You Want to Live Forever? transforms the tragic Battle of Stalingrad into a useful event for the Adenauer era. Most notably in the protagonist, Wisse, Wisbar's film offers a paradigm for individual conversion as the young lieutenant who firmly supported Hitler grows disillusioned and learns that he has been deceived. As a model for those Germans who supported National Socialism, this example suggests they need not examine their own actions critically, but instead simply transfer their faith and trust to the ideals of a new West Germany. Conversion also occurs in Wisbar's use of images. In his hands, archival footage becomes a means to teach the folly of blind obedience to authority. Beyond simply retelling the events of Stalingrad, Wisbar includes several scenes that take previous accounts of the battle and transform them into images that pointedly emphasize the suffering of the German soldier. Whether Germans thought of the Battle of Stalingrad as a "sacrifice" or of the Sixth Army as "victims," most Germans believed that soldiers had fought courageously. 


\section{Works Cited}

Baron, Ulrich. "Stalingrad als Thema der deutschsprachigen Literatur." Stalingrad: Mythos und Wirklichkeit einer Schlacht, edited by Wolfram Wette and Gerd R. Ueberschär. Fischer Taschenbuch, 1993, pp. 226-32.

Beevor, Anthony. Stalingrad. Viking, 1998.

Biess, Frank. "Survivors of Totalitarianism: Returning POWs and the Reconstruction of Masculine Citizenship in West Germany, 1945-1955." The Miracle Years: A Cultural History of West Germany, 1949-1968, edited by Hanna Schissler, Princeton UP, 2000, pp. 57-82.

Ellgaard, Helmuth. Hunde, wollt inr ewig leben? Official Press Packet, 1959.

“Frei nach Schiller,” Der Spiegel, 15 Apr. 1959.

Glantz, David M., and Jonathan M. House. When Titans Clashed: How the Red Army Stopped Hitler. UP of Kansas, 1995.

Hettling, Manfred. "Täter und Opfer? Die deutschen Soldaten in Stalingrad." Archiv für Sozialgeschichte, no. 35, 1995, pp. 515-31.

Dogs, Do You Want to Live Forever? (Hunde, wollt inr ewig leben?). Directed by Frank Wisbar, performances by Joachim Hansen, Wolfgang Preiss, Karl John, Wilhelm Borchert, Peter Carsten, and Sonja Ziemann, Deutsche Film Hanse, 1959.

Interview mit Hauptdarsteller Joachim Hansen. Hunde, wollt ihr ewig leben? DVD, Kinowelt, 2001. Kotulla, Theodor. "Hunde, wollt inr ewig leben?." Filmkritik, May 1959, pp. 117-18.

Krivosheev, G.F., et al. Soviet Casualties and Combat Losses in the Twentieth Century. Greenhill, 1997.

Kuby, Erich. Mein ärgerliches Vaterland. Hanser, 1989.

Kumpfmüller, Michael. Die Schlacht von Stalingrad: Metamorphosen eines deutschen Mythos. Fink, 1995. 
Miska, Peter. "Der Wahrheit dienen: Frank Wisbar's Stalingrad-Film." Frankfurter Rundschau, 4 Apr. 1959.

Moeller, Robert G. "In a Thousand Years, Every German Will Speak of This Battle: Celluloid Memories of Stalingrad." Crimes of War, edited by Omer Bartov, Atina Grossmann, and Mary Nolan, New P, 2002, pp. 161-90.

Moeller, Robert G. War Stories: The Search for a Usable Past in the Federal Republic of Germany. U of California P, 2001.

Overmans, Rüdiger. "Das andere Gesicht des Krieges: Leben und Sterben der 6. Armee." Stalingrad: Ereignis - Wirkung- Symbol, edited by Jürgen Foster, Piper, 1992, pp. 419-55.

Paul, Gerhard. "Krieg und Film in 20. Jahrhundert. Historische Skizze und methodologische Überlegungen." Krieg und Militär im Film des 20. Jahrhunderts, edited by Bernhard Chiari, Matthias Rogg, and Wolfgang Schmidt, Oldenbourg, 2003, pp. 3-78.

Polan, Dana. "Auteurism and War-teurism." The War Film, edited by Robert Eberwein, Rutgers UP, 2005, pp. 74-86.

Polan, Dana. Power and Paranoia: History, Narrative, and the American Cinema, 1940-1950.

Columbia UP, 1986.

Reichel, Peter. Erfundene Erinnerung: Weltkrieg und Judenmord im Film und Theater. Hanser, 2004.

Richnow, Götz. “Hunde, wollt ihr ewig leben?" Länder Informationsdienst, Stuttgart, 18 Jan. 1959.

Roos, Hans-Dieter. “Hunde, wollt ihr ewig leben?” Süddeutsche Zeitung, 15 May 1959.

Sands of Iwo Jima. Directed by Allan Dwan, performances by John Wayne, John Agar, Forrest Tucker, and Adele Mara, Republic Pictures, 1949.

Sigl, Klaus, et al., eds. Jede Menge Kohle? Kunst und Kommerz auf dem deutschen Filmmarkt der Nachkriegszeit, Filmpreise und Kassenerfolge 1949-1985. Filmland P, 1986.

Ueberschär, Gerd R. "Die Schlacht von Stalingrad in der deutschen Historiographie." Stalingrad: 
Mythos und Wirklichkeit einer Schlacht, edited by Wolfram Wette and Gerd R. Ueberschär. Fischer Taschenbuch, 1993, pp. 192-204.

Von Manstein, Erich. Verlorene Siege. Bernard \& Graefe, 1981.

Wette, Wolfram. "Das Massenterben als 'Heldenepos'." Stalingrad: Mythos und Wirklichkeit einer Schlacht, edited by Wolfram Wette and Gerd R. Ueberschär. Fischer Taschenbuch, 1993, pp. 4360.

Wieder, Joachim. Stalingrad und die Verantwortung des Soldaten. Nymphenburger, 1962.

Wieder, Joachim, and Heinrich Graf von Einsiedel, eds. Stalingrad und die Verantwortung des Soldaten. Herbig, 1993.

Wisbar, Frank. Hunde, wollt ihr ewig leben? Official Press Packet, 1959.

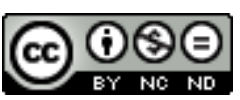

Creative Commons Attribution-NonCommercial-NoDerivatives 4.0 International License 